\title{
Geoinformation Methodology of Agricultural Land Evaluation for Agricultural Economic Growth
}

Elena Denisova

Federal Scientific Center of Agroecology, Integrated Land Reclamation and Protective Afforestation of the Russian Academy of Sciences, Volgograd, Russia

\begin{abstract}
The formation of an economically developed management system for the country's agro-industrial complex cannot be considered only from the point of view of a separate science. Land resources are the source of profit, which is involved in almost all sectors of society. Land preservation and improvement is required to ensure an economic security and competitiveness of each region of the Russian Federation). The dynamics of changes in the areas of Svetloyarsky district of the Volgograd region in the context of municipalities is analyzed. The actual deviation of the area of Privolzhsky rural settlement amounts to 2,3\% of the statistical data. The boundaries and areas of the used plots of arable land in the Raigorod settlement do not coincide with the data of the state cadastral registration, the discrepancy of only one land plot is 422,44 hectares. By implementing GIS-technologies, the data were obtained for 2355 arable land plots, whereof the irrigated land area amounts to 52138 hectares, instead of the potentially possible 19455 hectares, that exceeds the settlement's capabilities by 2,7 times according to the statistical data.
\end{abstract}

\section{Keywords}

GIS-technology, land quality, monitoring, tax, evaluation, cost, management, registration.

Denisova, E. (2021) "Geoinformation Methodology of Agricultural Land Evaluation for Agricultural Economic Growth", AGRIS on-line Papers in Economics and Informatics, Vol. 13, No. 4, pp. 3-8. ISSN 1804-1930. DOI 10.7160/aol.2021.130401.

\section{Introduction}

Land resources are not only a mean of getting products and raw materials for manufacturing, but also a natural resource on which depend ecological, social, recreational and cultural conditions of each region. Efficiency of agricultural land management especially during the period of land transformations is a guarantee of sustainable formation of all subjects of land relations.

The land management system provides for the consideration of legal, political, organizational, economic, environmental and social conditions of the state development. And it is impossible to consider the land management only as a separate branch of the state, because in the modern conditions of the agro-industrial complex development the land acts as an object both of legal relations and real estate, which forms a taxable base, collection of land payments, attraction of investments in the development of municipalities and regions (Borkhunov and Sagaidak, 2011; Kazankov, 2010).

The purpose of the research is to assess the spatial layout of the non-irrigated and irrigated arable land in the territory under study, give an assessment with the qualitative characteristics of each of them, identify discrepancies in the cadastral registration and actual use of land, create a local geo-information system for the regional characteristics of the distribution and the use of irrigated land.

The purpose of research is to determine the significance of modern geoinformation methods for identifying quality and quantity indicators of land, allowing to get relevant and reliable information in a short time that significantly effects the development of the economic sector of a particular region.

The land fund of the Volgograd region is strategically important due to the unique natural and geographical conditions, opportunities to get various types of agricultural products (Denisova and Silova, 2019). The region belongs to the most developed territories, and further expansion of agricultural land area is almost impossible. With the total area of 11287.0 thousand hectares, 
almost $82 \%$ accounts for agricultural land, of which $63 \%$ is arable land, $21,5 \%$ is pastures, the rest of the land is less than $20.0 \%$.

However, the most current issue of the region is deterioration of the soil quality of agricultural land, due to natural, agricultural zoning and high anthropogenic impact (plowing, irrigation, etc.) (Maler, 1990).

Improving land quality, preservation, prevention of degradation and desertification is a priority task of the state at all levels of government - the state (municipal) and private.

\section{Materials and methods}

Among the existing methods of assessment on land degradation and preservation of land quality the most interesting are those that provide a forecast of changes which occur on agricultural land, with a real variation of external and internal factors that determine such changes.

Modern land quality research methods are based on aerospace research methods in conjunction with geoinformation technologies and computer modeling.

For this purpose, geoinformation and local data sources are used, the electronic space maps are taken to display the general condition and the location of the research object (Tsifrovaya baza dannykh vysot and Tsentr nauchnykh dannykh Sentinels, 2018). These maps are based on digital topographic model of satellite imagery in a GIS environment in the form of thematic map by the QGIS 3.12 program.

Ground remote sensing data are represented by various survey methods, types of aircrafts, geolocation accuracy and resolution of the obtained image. Currently, there are freely available bitmap images with a pixel size of $1 \mathrm{~cm}$ (unmanned aerial vehicles), $30 \mathrm{~cm}$ (color-synthesized space images of World View 4 satellite), $10 \mathrm{~m}$ (multispectral space images in separate channels of the optical range of Sentinel 2 satellite), the use of the last mentioned ones provides the possibility of assessing the agricultural land use. The preservation of soil fertility, the identification of degradation processes, their dynamics is a necessary requirement for improving the efficiency and sustainability of land use.

Nowadays satellite imagery is the most important source of objective information about the research objects (Lidin, 2018 and Roy, 2014). The most accessible for research is satellite imagery from the satellites: Sentinel 2, Landsat-8 or Landsat-7 and others located on GIS services for free use and allow carrying out the full range of research in order to obtain information about condition, quality and agricultural land use (Erol, 2005). The maps are developed based on digital topographic model of space images corresponding to research objects in the GIS environment in the form of thematic raster, vector and attribute layers (Amin, 2012).

Soil mapping was carried out by the QGIS 3.12 program sequentially overlaying several high-resolution mapping layers and raster images on each other. The research consisted of several stages. The first stage was to overlay contours on the space image obtained by digital relief model (according to SRTM). Further, the boundaries of administrative regions were overlaid on the obtained map scheme. The next stage was to overlay thematic layers (agricultural land, terrain, soil contours, field contours). This approach allows carrying out full range of researches to get information about conditions, quality and agricultural land use (Denisova, 2021).

\section{Results and discussions}

The issue of preserving and improving the quality of land is relevant for all municipalities of the Volgograd region and especially for areas with a high anthropogenic load due to the close location of the administrative center - Volgograd.

The differentiation of the Volgograd region into three land-assessment areas clarified Svetloyarsky district to the third one, with a medium -meter soil point - 50, reflecting the smallest fertility (Table 1).

The favorable geographic location and the developed transport infrastructure of the region provide favorable conditions for industrial cooperation, allow the sale of products of the agro-industrial sector to the northern and southern regions of Russia. The municipal district has 1 urban and 9 rural settlements.

The dynamics of the area changes of municipal settlements shows the significant deviations both upwards and downwards (Table 2). Continuous erosion, the transfer of agricultural land to other categories, in particular to the category of land settlements, agricultural land transactions lead to significant changes in the structure of the land fund.

The main problem of agricultural land is the availability of alkali soil and salt complexes of $62.7 \%$, as well as salinization of soils of $30.5 \%$. 


\begin{tabular}{|c|c|c|c|c|c|}
\hline \multirow{2}{*}{$\begin{array}{l}\text { № Land- } \\
\text { assessment area }\end{array}$} & \multicolumn{2}{|c|}{ Land-assessment plot area } & \multicolumn{2}{|c|}{ Cadastral value } & \multirow{2}{*}{$\begin{array}{l}\text { Geometric mean } \\
\text { soil rating }\end{array}$} \\
\hline & ths. ha & $\%$ & ths. rub/ha & $\%$ & \\
\hline I & 2595.5 & 28.1 & 28899 & 61.5 & 85 \\
\hline II & 1688.8 & 18.3 & 11821 & 25.1 & 62 \\
\hline III & 4959.3 & 53.6 & 6299 & 13.4 & 50 \\
\hline Total & 9243.6 & 100 & 47019 & 100 & 62 \\
\hline
\end{tabular}

Source: own processing

Table 1: Weighted average cadastral value for land-assessment areas.

\begin{tabular}{|l|c|c|c|}
\hline \multirow{2}{*}{ Name of municipal settlement } & Area (ha) & Area (ha) & Area (ha) \\
\cline { 2 - 4 } & 1942 & 1963 & 2015 \\
\hline Svetloyarskoe & 45168.23 & 45173.07 & 39442.0 \\
\hline Bolshechapurnikovskoe & 15802.26 & 15806.55 & 16263.0 \\
\hline Dubroovrazhnoe & 19959.93 & 19956.56 & 19510.0 \\
\hline Kirovskoe & 18300.12 & 18294.63 & 15080.2 \\
\hline Narimanovskoe & 42999.89 & 43004.85 & 43023.0 \\
\hline Privolzhskoe & 39224.98 & 39235.16 & 38365.1 \\
\hline Privolnenskoe & 40848.5 & 40845.73 & 40860.0 \\
\hline Raigorodskoe & 26580.46 & 26586.82 & 27246.0 \\
\hline Tsatsynskoe & 50948.00 & 50960.13 & 51718.0 \\
\hline Chervlenovskoe & 26961.53 & 26970.75 & 26993.0 \\
\hline Total & 326793.90 & 326844.25 & 318500.3 \\
\hline
\end{tabular}

Source: research findings

Table 2: Summary of municipal settlements areas of Svetloyarsky district.

Unfortunately, registration of quantity and quality changes (erosion, deflation, overvoltage, wipping, salinization, salmon, stony and others) is done through collecting and processing the statistical data that do not reflect the current land condition and use.

Such researches were carried out in the Volgograd region in 2005 as a part of the first stage of cadastral valuation of agricultural land.

The cadastral valuation included two main stages:

- assessment of landowners' agricultural land by several factors: soil fertility, technological properties and location;

- valuation of landowners' agricultural land by land rent and cadastral value.

However, such researches are not precise and reliable, as they present the land conditions of 2004 .

GIS-technologies allow to survey large areas in a shorter time, to get reliable information about use of land plots, their areas, cultivated products, the presence of trees, shrubbery and forest vegetation, as well as to identify whether the fields are covered with crops or not Bazzi (2019).
Carrying out of systematic cartographic tracking of the processes caused by the human economic activity allows to create thematic cards of dynamics and forecast these modifications (Papaskiri, 2013).

The use of remote sensing techniques for land registration in the territory of Svetloyarsky district made it possible to examine agricultural land on the area of 253640.0 hectares or $79.6 \%$.

Having implemented GIS technologies with aerospace research methods at assessment of the territory the boundaries and the plots of the used non-irrigated and irrigated land were clarified, as well as the individual characteristics of each one (an angle of the slope, exposition, height difference and others) were defined. The picture 1 presents the use of irrigated and non-irrigated arable land.

To obtain this electronic space map, the images of satellite Sentinel 2 were used dated 08.07.2020 ID:L1C_T38UMU_A 026344-2020-07-0 8 and ID: L1C-T38UNU-A026344-20200708.

The main advantages of implementing space imageries and digital data obtained during remote sensing are as follows: they cover extensive and hard-to-reach territories in a single moment 


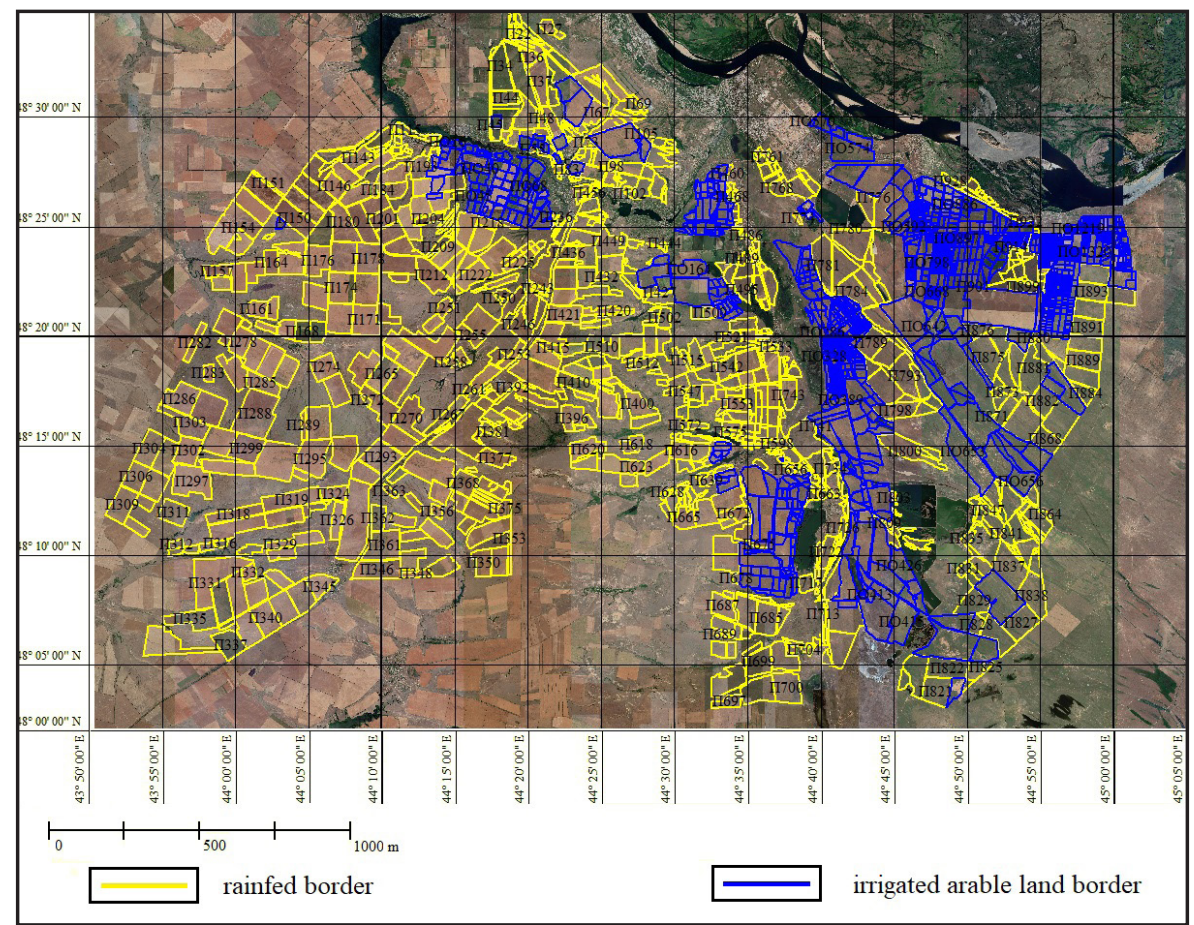

Source: Authors

Figure 1: Space map image of irrigated and non-irrigated arable land in Svetloyarsky district of the Volgograd region.

of time, have the resolution of the appropriate characteristics of the applied equipment, give an integrated image of all elements of the earth's surface allowing determine their structure and communication, and also conduct any seasonal space monitoring of agricultural systems, in other words to fix the state of objects at different points in time and trace the dynamics of their changes.

This approach of registration the quantity and the quality of land, namely irrigated and non-irrigated is innovative, as the researches with application of GIS technologies in the territory of the Volgograd region were not conducted yet.

With the help of the current research methods the boundaries of 2.355 plots of arable land in Svetloyarsky distrikt were clarified, of which 1.424 land plots were irrigated and 931 ones were non-irrigated. The area of non-irrigated land amounts to 139540.0 hectares, and the irrigated one is 52138.0 hectares.

The main issue of the district land use is an uncontrolled irrigation which leads to a shallow contour of land, indented boundaries, and a loss of soil fertility. Irrigated land is a prerequisite for getting high stable yields in the Volgograd region, and it is simply vital for some municipalities.

In Svetloyarsky municipal district for the period from 2009 to 2016 the area of irrigated land changed from 1555 hectares to 5282 hectares, it means that it increases of 3,727 hectares. With the help of irrigation grow grain, fodder and industrial crops, vegetables, melons, perennial plantings in irrigated area of 3450 hectares. The picture 1 shows the use of non-irrigated and irrigated arable land.

According to the data of Federal State Budgetary Institution "Upravlenie "Volgogradmeliovodkhoz" there were 9557 hectares of regularly irrigated land in the territory of the surveyed area in 2016. But according to the statistics data, the region's capabilities amount to 19455 hectares, but the geoinformation research indicates that actual use of irrigable areas had been 2,7 times more, instead of 19455 hectares were used 52138 hectares.

\section{Conclusion}

Modern methods admit obtaining spatial data about condition and main characteristics of arable land plots. Both allocation and mapping of plots for arable land as well as specifying their present condition during the survey are important for the Volgograd region. Thus, these methods allow to increase the efficiency of land management.

Application of remote research methods of agricultural land in combination with geoinformation technologies make it possible 
to determine not only the spatial location of areas that are subject to agricultural production, but also to establish the nature, level and application features, as well as to differentiate into irrigated and non-irrigated land.

This differentiation allows drawing up a steady mechanism for economic land management aimed at implementing the land policy of the state, ensuring the rights of landowners and land users, establishing socially just land payments, promoting rational and effective land use, imposing sanctions for deterioration of the ecological condition of land plots, protecting land from damage, illegal seizure, unuse and others Eremchenko (2011), Khlystun (2019).

The total area of land to be recorded within the borders of Svetloyarsky district is 282955,24 hectares. Agricultural land accounting based on the geo-information study in view of several municipal settlements of the district provided an opportunity to identify the discrepancies in the areas of land, the list of irrigated land and the arrangements for using.

In Privolzhskoe municipal district the discrepancies were revealed in the area of the settlement itself. According to the results of the study, its area decreased by $2,3 \%$ (1071 ha) in comparison with the statistical data.

In Raigorodskoe rural settlement, the plots used for agricultural production were identified, but they haven't passed the state cadastral registration. According to the results of the space mapping of Svetloyarsky district, the area of the used land amounts to 181,28 hectares with reference to the cadastral unit 34:26:100601. But in compliance with the Federal Service for State Registration, Cadastre and Cartography only 33,02 hectares of land are registered. Referring to the cadastral unit 34:26:120203, the irrigated land plot (PO411) within the actual boundaries of 96,9 hectares is used and a plot of non- irrigated land P817 of 650,29 hectares is used, however, only arable land is subject to registration within the area of ZU: 2221 - 168.75 hectares and ZU: 121-156.0 hectares. Indeed, the discrepancy between the used and registered areas is 422.44 hectares. The areas of the used arable land and registered ones in Chervlenovsky rural settlement have significant discrepancies (Savu and Raboj, 2014).

The methods of conducting such agricultural land studies are particularly relevant to keeping accounting for land resources, their legal use, the formation of regional tax base, which includes land tax; rental fee; market price; loan price; compensation for land taken; compensation for land conservation; payments for improving land quality and soil fertility; fines for environmental damage; taxation in civil land turnover and others Lidin (2018).

Proposed solutions:

- to monitor, account and observe the quantitative and qualitative changes in land resources in the view of each municipal settlement by the modern geoinformation technologies;

- to differentiate land into irrigated and non-irrigated with clarification of actual boundaries and their use;

- to carry out a state cadastral registration of irrigated land and fill in data in the real estate register;

- to legislate the concept of "irrigated land" in order to specify the necessary set of characteristics (degree of wetting, soil texture, slope, fertility and others);

- to double the cadastral value of irrigated land and to use the existing tax base as follows: $0.3 \%$ for non-irrigated land; $1.5 \%$ for irrigated one.

Corresponding authors

Denisova Elena Vladimirovna

Federal Scientific Center of Agroecology, Integrated Land Reclamation and Protective Afforestation of the Russian Academy of Sciences

University ave, 97, 400062, Volgograd, Russia

Phone: +79173321239,E-mail:denisov.00@mail.ru

\section{References}

[1] Amin A. and Fazal, S. (2012) "Quantification of Land Transformation Using Remote Sensing and GIS Techniques ", American Journ of Geographic Information System, Vol. 1, No. 2, pp. 17-28. ISSN 2163-1131. DOI 10.5923/j.ajgis.20120102.01. 
[2] Bazzi, H., Baghdadi, N., El Hajj, M., Zribi, M., Minh, D. H. T., Ndikumana, E., Courault, D. and Belhouchette, H. (2019) "Mapping Paddy Rice Using Sentinel-1 SAR Time Series in Camargue, France", Remote Sens, No. 11, pp. 887. E-ISSN 2072-4292. DOI 10.3390/rs11070887.

[3] Borkhunov, N. A. and Sagaidak, E. A. (2011) "Economic relations in agriculture in the conditions of transition to innovative development", All-Russian Research Institute of Agricultural Economics, Moscow, p. 184.

[4] Denisova, E. V. and Silova, V. A. (2019) "The current state analysis of the agro-forest landscape components based on the geoinformational systems usage", IOP Conference Series: Earth and Environmental Science, Krasnoyarsk Science and Technology City Hall of the Russian Union of Scientific and Engineering Associations, Vol. 315, No. 5. E-ISSN 1755-1315. ISSN 1755-1307. DOI 10.1088/1755-1315/315/5/052062.

[5] Denisova, E.V. (2021) "Geoinformation analysis of agricultural landscape components for land management, cadastre and monitoring of irrigated lands", Geodezia i Kartografia, Vol. 967, No. 1, pp. 56-64. E-ISSN 2587-8492, ISSN 0016-7126. DOI 10.22389/0016-7126-2021-967-1-56-64. (in Russian).

[6] Eremchenko, E. (2011) "A new approach to implementing of GIS for small municipalities", ArcReview, Vol. 2, No. 32, pp. 12-18.

[7] Erol, H. and Akdeniz F. A. (2005) "Per-field classification method based on mixture distribution models and an application to Landsat Thematic Mapper data", International Journal of Remote Senssing, No. 26, No. 6, pp. 1229-1244. E-ISSN 1366-5901, ISSN 0143-1161. DOI 10.1080/01431160512331326800.

[8] Kazankov, V. A. (2010) "Problems of rational use of ground resources in the Volgograd region", South of Russia: ecology, development, No. 4, pp. 96-98. E-ISSN 2413-0958, ISSN 1992-1098. DOI 10.18470/1992-1098-2010-4-96-98. (in Russian).

[9] Khlystun, V. N. (2019) "Development of land relations in the agroindustrial complex", Herald of the Russian Academy of Sciences, No. 4, pp. 325-332. E-ISSN 1555-6492, ISSN 1019-3316. DOI 10.1134/S1019331619040038.

[10] Lidin, K. L., Meerovich, M.,G., Bulgakova, E. A., Vershinin, V. V. and Papaskiri, T. V. (2018) "Applying the theory of informational flows in urbanism for a practical experiment in architecture and land use", Espacios, Vol. 1, No. 39, p. 12. ISSN 0798-1015.

[11] Maler, K. (1990) "Economic Theory and Environmental Degradation: a Survey of Some Problems", Revista de Analisis Economico, No. 5, pp. 7-17. ISSN 0718-8870.

[12] Papaskiri, T. V. (2013) "Informacionnoe obespechenie zemleustrojstva" (Information support of land management), Moscow: publishing company "GUZ". 160 p. (In Russian).

[13] Roy, D. P., Wulder, M. A. and Loveland, T. R....Zhu, Z. (2014) "Landsat-8: Science and product vision for terrestrial global change research", Remote Sensing of Environment, No. 145. p. 154-172. ISSN 0034-4257. DOI 10.1016/j.rse.2014.02.001.

[14] Savu, A. and Raboj, D. (2014) "Cadastral Documentation in Real Valuation", The Valuation Journal, Vol. 9, No. 1, pp. 54-71. ISSN 1842-3787.

[15] Tsifrovaya baza dannykh vysot (CGIAR-CSI) (2018) [Online] Available: http://srtm.csi.cgiar.org [Accessed: 18 Jan. 2021]. (in Russian).

[16] Tsentr nauchnykh dannykh Sentinels (ESA-COPERNICUS) (2018) [Online] Available: https://scihub.copernicus.eu/dhus [Accessed: 18 Jan. 2021]. (in Russian).

[17] Vershinin, V. V., Murasheva, A.A., Shirokova, V. A., Khutorova, A. O., Shapovalov, D. A. and Tarbaev, V. A. (2016) "The Solutions of the Agricultural Land Use Monitoring Problems", International Journal of Environmental \& Science Education, Vol. 11, No. 12, ISSN 5058-5069. 